\title{
NEW SPECIES OF PTEROPUS, MUS, AND POGONOMYS FROM THE AUSTRALIAN REGION.
}

\author{
By OLDFIELD THOMAS.
}

The following new mammals are among the collections recently obtained in Papuasia and Australia by Messrs. Meek, Tunney, and Pratt.

\section{Pteropus solomonis spec. nov.}

A small species allied to $P$. brunneus and aneiteanus, with short ears; the hind-limbs furred two-thirds down the tibiae.

Size about as in $P$. aneiteanus. Fur short, woolly for the most part, but straight and smoothly adpressed on the middle third of the back, where it is about 2 in. across. A line along the onter side of the proximal third of the forearm thinly clothed with fine brown hair. Upper surface of hind-limbs covered with woolly hair about two-thirds down the tibiae, the ankles and feet naked.

Ears short and narrow, their anterior edge evenly convex, tip narrowly rounded, outer edge faintly concave above, convex below.

Colour of head brown ("hair-brown"), the end of the muzzle with a whitish sheen ; woolly hair of occiput, nape, and shoulders coppery rufous (between russet and walnut-brown of Ridgway). Straight hairs of back "seal-brown." Woolly hair of rump and hind-legs brown, with shining coppery ends. Below, the throat and sides of the chest and belly are dull rufous brown, darkening along the centre line to blackish brown.

Skall light and delicate, the braincase of the same narrow form as in $P$. aneiteanus. Palate narrow, the toothrows evenly divergent, not curved. Upper incisors broad and spatulate, touching one another. Canines small. Anterior upper premolars present, but exceedingly minute. Sizes of molars about as in $P$. aneiteanus (see dimensions).

Dimensions of the type :-

Forearm, $108 \mathrm{~mm}$.

Head and body (skin), 180 mm.; ear (dry), 16 ; thumb (s.u.), 38 ; tibia, 50 ; lower leg and foot (c.u.), 80.

Skull, greatest length (c.), $54 \mathrm{~mm}$. ; tip of nasals to angle behind postorbital processes, $24 \cdot 3$; interorbital breadth, $6 \cdot 7$; breadth of braincase, 19 ; length of palate from gnathion, 29.3 ; breadth between inner sides of $\mathrm{m}^{1}$, upper incisive row, $7 \cdot 3$; length of canine from cingulum, behind, 5 ; horizontal length of last premolar, $3 \cdot 9$; of $\mathrm{m}^{1}, 4 ; \mathrm{m}^{2}, 5 \cdot 1 ; \mathrm{m}^{3}, 1 \cdot 8$. Below, length of canine, $4 \cdot 1$; horizontal lengths of the six cheek teeth in succession, $2,3 \cdot 8,3 \cdot 9,4,3 \cdot 2,1 \cdot \%$.

Hab. Gizo Island, Solomons.

Type: an old female, B. M. No. 4. 4. 11. 1. Collected November 10th, 1903, by Mr. A. S. Meek.

This species differs from $P$. aneiteanus by the nakedness of the lower part of the tibia and the absence of the whitish hairs on the shoulders, and from $P$. brunneus by its smaller size and much smaller teeth. Its coloration is not unlike that of $P$. brunneus, allowing for the fading of Dobson's type. 


\section{Mus verecundus spec. nov.}

A peculiarly built species, with long slender feet. Mammae $1-2=6$.

Size about as in Mus rattus. Fur soft and straight, hairs of back abont $15 \mathrm{~mm}$. in length, a small number of softer piles, abont $20 \mathrm{~mm}$. long, intermixed on the hinder back. Whiskers unusually; strong and numerous. General colour above sepia-brown, faintly " ticked"* with buffy. Undersurface dull slaty buffy, not defined laterally, the bases of the hairs broadly slate-coloured, the tips dull buffy ; chin not lighter. Head greyish, darker than back, and with less buffy suffusion. Ears short, laid forward in a spirit specimen they barely reach to the middle of the eye, practically naked, slaty grey. Arms and legs coloured like the body, scarcely lighter on their inner surfaces; upper surface of metacarpns brown, digits white; hindfeet unusually long and slender, the lengthening being mainly in the metatarsus; soles naked, smooth, the last pad elongate, fifth hindtoe nearly reaching (withont claw) to the middle of the first phalanx of the fourth; upper surface of metatarsus brown, digits lighter. Tail rather longer than the head and body, evenly ringed (scale-rings about 10 to the centimetre), finely haired, not pencilled, thongh rather more hairy terminally; hairs abont $1 \frac{1}{2}-$ 2 scales in length; uniformly brown above and below, the terminal $\frac{1}{2}$ in. white. Mammae $1-2=6$; the anterior behind the axillae ; clitoris very long.

Skull smooth and rounded, the braincase small and the muzzle remarkably long. Nasals long, narrow behind, much expanded anteriorly. Supraorbital edges, even in old specimens, but very slightly ridged, the ridges quite inconspicuons where they cross the parietals. Interparietal fairly large. Anterior edge of zygomatic plate slanting, scarcely convex. Palatal foramina large, widely open, just reaching to the level of the front root of $\mathrm{m}^{1}$. Palate ending well behind $\mathrm{m}^{3}$. Bullae small.

Incisors narrow, smooth in front. Molars worn down in both Aroa specimens, but apparently-and in the Dinawa specimens-of a very simple murine type. In one of the latter examples, young, the molars, as compared with those of Mus rattus, are very similar, with the exception that there is no antero-external supplementary cusp on $\mathrm{m}^{2}$, or external one on the second lamina of $\mathrm{m}_{2}$.

Dimensions of the type, measured in skin :-

Head and body (stretched), $170 \dagger \mathrm{mm}$. ; tail, 168 ; hindfoot, 34 ; ear, 18.

Skull, greatest length, $40.5 \mathrm{~mm}$; basilar length, 32 ; zygomatic breadth, 18 ; nasals, $15 \cdot 2 \times 4 \cdot 8$; interorbital breadth, 6 ; breadth of braincase, 16 ; interparietal, $5 \times 9$; zygoma root, $3 \cdot 4$; palate length from henselion, $18 \cdot 6$; diastema, 11 ; palatal foramina, $7 \cdot 1 \times 3$; length of upper molar series, $6 \cdot 7$.

Hab. Avera, Aroa River, British New Guinea.

Type: an old female. B. M. No. 3. 12.1.1. Collected May 31st, 1903, by A. S. Meek.

Two specimens.

Two other specimens, in spirit, apparently of the same species, were collected at Dinawa, Owen Stanley Range, altitude 4000 ft., by Mr. A. E. Pratt.

* From the French tiqueté. A word to express a colour smoother and less coarsely variegated than "grizzled" or "mottled" is often wanted in writing descriptions of mammals, and "ticked" might be made to serve the purpose.

$\dagger$ True head and body length probably about $150 \mathrm{~mm}$. 
This rat is a very peculiar one, and I have considerable donbt whether it onght to be put in Mus at all, but in the absence of marked differential characters of generic importance I do not think it advisable to form a genus for it at present.

\section{Mus colletti spec. nov.}

A dark-coloured spinons rat, with $3-3=12$ mammae.

Size medium. Fur of medium length, ordinary hairs of back about $12 \mathrm{~mm}$. in length, liberally mixed on the rump with longer piles attaining $30 \mathrm{~mm}$., and also, to a very variable extent, with flattened spines, about $12 \mathrm{~mm}$. long and $\frac{1}{4} \mathrm{~mm}$. in breadth. General colour above heavily lined grizzled greyish brown, not nnlike that of Mus sordidus, Gould, the spinous hairs and the long piles broadly tipped with black, the others with creamy buff, the latter colour becoming rather more dominant on the sides. Undersurface pale soiled buffy, not sharply defined, the slaty bases of the hairs showing through. Face dark grizzled grey, like back. Ears of medium size, almost naked, brown, their extreme edges lighter. Outer side of arms and legs like back, inner sides like belly; upper surface of hands and feet dull whitish or brownish white. Tail rather shorter than head and body, prominently scaled (12 rings to the .centimetre), well haired, the hairs averaging about 2 scales in length proximally, shorter and less numerous terminally; uniformly black. Mammae, $3-3=12$.

Skull not unlike that of $M$. sordidus in general shape, though smaller; the interorbital region similarly narrow, its edges margined by a well-marked bead running back to the outer corners of the interparietal. Zygomatic plate broad, convex above. Palatal foramina long, narrow, reaching back to the anterior lamina of $\mathrm{m}^{1}$. Bullae fairly large.

Dimensions of the type, measured in skin :-

Head and body, $136 \mathrm{~mm}$. ; tail, 107 ; hindfoot, 29 ; ear, 16.

Skull, basilar length, $31 \mathrm{~mm}$; zygomatic breadth, 18.5 ; nasals, length, 12.5 ; interorbital breadth, $4 \cdot 7$; braincase, breadth, $14 \cdot 6$; zygomatic plate, $4 \cdot 2$; palate, length, $17 \cdot 3$; diastema, 10 ; palatal foramina, $7 \cdot 3 \times 2$; length of upper molar series (worn down), $6 \cdot 3$; of another specimen, $6 \cdot 6$.

Hab. S. Alligator River, Northern Territory, Australia.

Type: an old female. B. M. No. 4. 4.4.4. Original number, 1838 . Collected Angust 30th, 1903, by Mr. J. T. Tunney; presented to the British Museum by the Hon. Walter Rothschild.

"Dug out of hole in open clay flats."

Twenty-five specimens examined.

This rat is perhaps a tropical representative of Mus sordidus, which it resembles in its dark colour and general characters; but it is smaller than that species, and far more harshly clothed, $M$. sordidus being quite a soft-furred animal. Correlated with the harshness of the fur the strong lining of the back is unusually conspicuous, almost resembling in this respect the members of the genus Sigmodon.

I have named this species in honour of my friend Dr. Robert Collett, of Christiania, the anthor of the chief paper on the mammals of the region in which it occurs.* 


\section{Pogonomys dryas spec. nov.}

Closely allied to $P$. mollipilosus, but ears much larger.

Size, proportions, and other essential characters as in $P$. mollipilosus. General colour above dull buffy brown; head and sides lighter and denser buffy. Undersurface pure sharply defined white. Ears of medium size ; laid forward in the spirit specimen they reach to the centre of the eye ; their front edge nearly straight, end broadly rounded; practically naked, pale greyish. Upper surface of hands and feet white or brownish white. Tail long, finely scaled (12 rings to the centimetre), practically naked, pale brown throughout* except on the naked and prehensile terminal portion above, which is pale flesh-coloured. Mammae $1-2=6$.

Skull closely similar to that of $P$. mollipilosus, but slightly larger; frontal region flatter; braincase smaller; palatine foramina more strongly curved; but the differences in all cases very slight.

Teeth of the typical Pogonomys pattern, not of the more complicated Chiruromys type; their size and structure quite as in $P$. mollipilosus.

Dimensions of the type, measured in spirit :-

Head and body, $114 \mathrm{~mm}$; tail, 184 ; hindfoot, 23.5 ; ear, from notch, 15 ; from crown, $12 \cdot 3$; breadth, 118.

Sknll, greatest length, $32 \mathrm{~mm}$; basilar length, $27 \cdot 6$; greatest breadth, $18 \cdot 7$; nasals, $11 \times 3.3$; interorbital breadth, 4.4 ; breadth of braincase, 14.8 ; palate length, 15 ; diastema, 9.8 ; palatal foramina, $4.5 \times 2.9$; length of upper molar series, $6 \cdot 3$.

Hab. Dinawa, Owen Stanley Range, British New Guinea; altitude $1300 \mathrm{~m}$.

Type: an adult female in spirit. B. M. No. 4. 4. 10.6. Collected by Mr. A. E. Pratt.

Two skins from Avera, Aroa River (Coll. Meek).

This species is very closely allied to $P$. mollipilosus Peters \& Doria, obtained at Katau, near the mouth of the Fly River, of which the typical skull has been kindly lent me by Dr. Gestro for comparison. That animal, however, has so much smaller an ear (length from notch $11 \mathrm{~mm}$., above crown $9 \cdot 2$, breadth 9 ), that I do not feel justified in assigning the Dinawa form to it; moreover, its tail is differently coloured, being brown for its basal third only, then marbled, and finally wholly yellow above and below.

* The Avera specimens have a few pale markings on the middle third of the tail. 


\section{$2 \mathrm{BHL}$ Biodiversity Heritage Library}

Thomas, Oldfield. 1904. "New species of Pteropus, Mus, and Pogonomys from the Australian region." Novitates zoologicae : a journal of zoology in connection with the Tring Museum 11, 597-600. https://doi.org/10.5962/bhl.part.26839.

View This Item Online: https://www.biodiversitylibrary.org/item/24181

DOI: https://doi.org/10.5962/bhl.part.26839

Permalink: https://www.biodiversitylibrary.org/partpdf/26839

\section{Holding Institution}

Natural History Museum Library, London

\section{Sponsored by}

Natural History Museum Library, London

\section{Copyright \& Reuse}

Copyright Status: Public domain. The BHL considers that this work is no longer under copyright protection.

This document was created from content at the Biodiversity Heritage Library, the world's largest open access digital library for biodiversity literature and archives. Visit BHL at https://www.biodiversitylibrary.org. 